ORIGINAL ARTICLE

\title{
The effect of three sport games in physical education on the health- related fitness of male university students
}

\author{
Mohammed H.H. Mohammed $\mathrm{ABD}$ \\ King Fahd University of Petroleum \& Minerals, Dhahran, Saudi Arabia
}

Authors' Contribution: A - Study design; B - Data collection; C - Statistical analysis*; D - Manuscript Preparation; E - Funds Collection*

\begin{abstract}
Purpose: $\quad$ Few controlled studies have been conducted on the effect of sports games as a physical education (PE) course on the health-related fitness of university students. The aim of the study was to determine whether three sports in a PE course will help improve the health-related fitness of male university students.

Material: $\quad$ Students from two universities participated in the study, with one university acting as a control group. There were two PE courses which students registered for: a football and volleyball (FVG, $n=169$ ) course and a badminton ( $B G, n=97)$ course. The students received basic training drills and competed with one another. The duration of the activities was 50 minutes sessions for eight weeks. The following tests were taken before and after eight weeks: Cooper test, sit-and-reach test, 60-s curl test, standing long jump test, and body mass index. Paired t-tests were used to compare the baseline and post data of each group. The Welch t-test, ANCOVA, and analysis of gains scores were used to compare each of the PE groups to the control group. ANCOVA was used to account for baseline differences, while analysis of gains scores was used whenever ANCOVA could not be used. The Vargha-Delaney Effect Size (VD) and the Common Language Effect Size (CLES) were used to determine the effect sizes for the Welch t-tests and ANCOVA, respectively. Significant changes were set at $\mathrm{p} \leq$ 0.05 and $V D \leq 42 \%$ or $V D \geq 58 \%$, or if $p \leq 0.05$ and $C L E S \geq 58 \%$.

Results: $\quad$ Both PE groups showed significant improvements in all the measured fitness parameters except body composition. Moreover, the measured parameters of the control group reduced after eight weeks.

Conclusions: The study shows evidence that PE courses can serve male universities in improving their health-related fitness. Moreover, students who do not participate in a PE course may be at risk of losing their fitness.

Keywords: football, volleyball, badminton, college, physical education.
\end{abstract}

\section{Introduction}

Physical education (PE) programs are designed to provide the necessary skills needed by students to perform physical exercises correctly [1]. Moreover, they provide basic information on the health benefits of physical activity [2]. Despite these benefits, some universities do not provide PE courses to university students unless they want to obtain a degree in the subject [3]. According to Cardinal [4], physical education as a requirement for graduation needs to be justified in some universities. At the same time, first year university students are interested in taking a basic PE course as they perceive they can obtain some benefits from the course [5].

Various researchers have investigated the ability of PE programs to improve the fitness levels of students. The aim of these studies was to show if PE programs could significantly contribute in providing the necessary amount of physical activity students need to be healthy. This is important considering that studies from several nations show a decline in health-related fitness levels in children [6-11] and adults [12-14]. Obesity increased twofold from 1980 according to the World Health Organization [15]. However, most of these studies evaluated the effect of PE courses on the health-related fitness of schoolchildren. Systematic reviews show that school-based interventions can improve the health-related fitness of school students if properly designed $[16,17]$.

(c) Mohammed H.H. Mohammed, 2020

doi:10.15561/20755279.2020.0408
In contrast to schoolchildren, few studies were conducted on the effect of PE activities on university students. These studies have shown that PE can improve the health-related fitness of university students. Nevertheless, most of these studies were not done with control groups. Considering that some universities do not provide PE courses to non-PE students, any appreciable benefit from such a course could be used by PE lecturers to promote the institution of PE courses as a graduation requisite. Thus, the aim of this study was to determine the effect of a PE activity program on the health-related fitness of male university students. The research hypothesis was that the PE program would improve their health-related fitness.

\section{Material and Methods}

Participants.

The students in the study were from two universities located in the Eastern Province of Saudi Arabia. The students from one of the universities served as the control group $(C G, n=80)$ as they did not do any PE course. The students in the PE group were from King Fahd University of Petroleum \& Minerals (KFUPM). There were two PE groups. The first group was the football and volleyball group ( $F V G, n=169$ ), while the second group was the badminton group ( $\mathrm{BG}, \mathrm{n}=97)$. None of the participants were PE majors.

The study was conducted in accordance with The Code of Ethics of the World Medical Association (Declaration 
of Helsinki) and approved by the Research Scientific Committee at the Physical Education Department of KFUPM. The participants signed consent forms.

\section{Research Design.}

The study was conducted in the first semester of the 2017-2018 academic year (within the 17 September 2017 - 28 December 2017).

Three games were provided to the students: Volleyball and football, and badminton. The courses were held twice a week for eight weeks. Each session was 50 minutes and had different training drills. Overall, the 50 minutes session was divided as follows: five minutes for warm-up, ten minutes for physical fitness, ten minutes for introducing and teaching the fundamental skills, 20 minutes for a practice game, and five minutes for cooldown and stretches.

Football

The students in the FVG received football training for four weeks. The training focused on the following aspects: (i) Improving the fundamental skills of the students, (ii) Increasing their cardiovascular endurance, (iii) Helping them improve their understanding between teammates, and (iv) Helping them with muscle development and strength through tactical drills, intense sprinting drills, and various exercises.

The students warmed up for five minutes using stretching and jogging. Then, they were given ten minutes of interval training after the warm-up. The interval training consisted of mixed footwork with maximal sprinting. To improve the explosive power of the students, the students were asked to do plyometric exercises such as push-ups, curl-ups, burpee, and jumping jack. These plyometric exercises also served to enhance other fitness aspects such as sprinting ability (speed \& agility), jumping skills, and the lower and upper body strength.

Ten minutes were for learning and developing fundamental skills such as passing, running with the ball, juggling, and shooting. Overall, the students were divided in groups of two to practice with each other while being monitored and corrected. Twenty minutes were given for a practice game after teaching the fundamental skills. The practice game was a means to improve their skills and their overall experience of the game. Finally, five minutes of cool-down exercises such as stretching or foam rolling of the upper and lower body were given to the students after each training session.

\section{Volleyball}

The students in the FVG received volleyball training for four weeks. The students performed five minutes of warm-up using slow jogging and the following plyometric exercises: push-ups, curl-ups, burpee, jump rope, and jumping jack.

Ten minutes was used to give several drills and skills to the students. The first drill was toss and pass whereby one player tossed an easy ball to the other player to pass. This was done for 50-100 repetitions and then the players switched roles. The second drill was setting and digging to the wall on their own. Here, the students set and dug the ball towards the wall to work on their fundamental skills.
The students were also taught wall blocks. In this drill, students would jump in front of a wall to imitate the act of blocking a ball. The purpose of wall blocks was to train the students on how to block without brushing the net with their arms on the way down after a block. One-on-one setting drills were also taught to develop consistent setting skills. This was achieved through repetitions setting; two students set back and forth to each other over the net. Serving skills were also taught. Here, two students, one standing on each side of the court, took turns serving to each other. The servers served to their partners standing in different areas of the court. To improve other aspects of game playing, the students learned about teamwork, the rules of the game, strategies, and skills.

The students also played a practice game for twenty minutes so that they could improve on their skills and their overall experience of the game. The students were given five minutes of cool-down exercises such as stretching or foam rolling of the upper and lower body after each training session.

\section{Badminton}

The students in the BG received badminton training for eight weeks. Badminton training focused on the physical and fundamental skills aspects of the game. Warm- up exercises were given for five minutes. The warm-up exercises included running, jumping stretching, push-ups, sit-ups, footwork, and some challenge games for 15 to 30 seconds. The footwork was also aimed at training the students on how to move inside the badminton court.

The skills taught during the ten minutes of skill training were proper racket grip, forehand and backhand, serve and return services, long and short shot, smash, and footwork in the court. The students were also taught the rules of badminton. The lecturer demonstrated how to execute the skills before choosing a student to repeat after the lecturer. Then they were divided into groups of two and each student per group was asked to get on both sides of the net. They were instructed to pass the shuttlecock to each other using the skills they were taught. Then they were corrected whenever they made mistakes during the 20 minutes of the practice period. They were also given correct tips one minute before the cool down session.

On the first day of the fifth week, the students played a game to practice all the skills. They played a round-robin competition from the second class of the fifth week up until the last week. Cool-down exercises and stretches were given for five minutes to conclude the class.

\section{Health-Related Fitness Testing}

The following health-related fitness tests were conducted: (i) Cardiovascular fitness using Cooper's test (ii) Muscular endurance and explosive strength using curl-up tests and standing long jump tests, respectively, (iii) Body composition using body mass index, (iv) Trunk flexibility using the sit-and-reach test. All parameters except for explosive strength were tested by the ACSM health-related fitness testing guidelines [18]. Body mass and height were measured with a stadiometer (Seca GmbH \& Co. KG, Hamburg, Germany). For the explosive strength, the students were asked to jump from a line 
marked on the floor and land with their two feet. Their toes were the behind line before the jump. The measurement was taken using a straight inelastic measuring tape taped to the floor. The length jumped was measured at the back of their heel.

All the fitness tests were demonstrated to the students before they proceeded. The students were encouraged to give their maximum effort during the pre and post-tests and they were reassured that the tests would not negatively affect their final grade.

Statistical Analysis

The paired t-test was used to compare the pre and post data of the groups. The exercise groups were not compared with each other as it was not the aim of this study. The Welch t-test was used to compare the baseline values of the exercise groups with the baseline values of the control group due to the inequality of sample sizes. Welch t-test to compare the post data was used in case there were no baseline differences. In case there were baseline differences, both ANCOVA and the analysis of the gains scores [19] were used to determine if there were differences between the exercise and control groups after eight weeks. The analysis of the gains scores was used when the following assumptions for ANCOVA were violated [20]: linearity of slopes, homogeneity of slopes, homogeneity of variance, and significant number of outliers. The analysis of gain scores utilized compared the mean differences of the PE groups to the CG using Welch t-test. Statistical significance was fixed at $\mathrm{p} \leq 0.05$. The Welch t-test and the analysis of the gains scores were performed with SPSS 16. The tests for the assumptions along with ANCOVA were performed with R [21].
The effect size measure was the common language effect size (CLES). When comparing within a group, the CLES tells you the probability that a person will experience a change after undergoing an intervention. When comparing groups, the common language effect size shows the probability that a person randomly selected from one group will have different measured parameters from another person randomly selected from another group [22]. The improved CLES by Vargha-Delaney (VD) was used whenever the Welch t-test was used [23]. VD values are more robust than CLES [23]. The VD values were calculated with the orddom package in $\mathrm{R}$ [24]. Changes in the tested parameters were considered significant if $\mathrm{p} \leq 0.05$ and $\mathrm{VD} \leq 42 \%$ or $\mathrm{VD} \geq 58 \%$. These VD thresholds were obtained from the effsize package in $\mathrm{R}$ [25]. When ANCOVA was used, the effect size estimator used was omega-squared which was calculated using the sjstats package in R [26]. The omega-squared value was then converted to CLES using an online psychometric calculator by Lenhard and Lenhard [27]. The conversion was done to improve the interpretation of the results [28]. The differences revealed by ANCOVA were considered significant if $\mathrm{p} \leq 0.05$ and CLES $\geq 58 \%$.

\section{Results}

Data for 346 students (FVG: $\mathrm{N}=169$; $\mathrm{BG}$ : $\mathrm{N}=97$, CG: $\mathrm{N}=80$ ) were analyzed. The control group had a greater overall fitness than the PE groups as shown in Table 1. Table 2 shows the changes in fitness from pre to post in all the groups. There were increases in the fitness measures from pre to post for in the exercise groups after eight weeks, whereas there was a reduction in fitness measures

Table 1. Differences in baseline data of exercise groups to control group

\begin{tabular}{|c|c|c|c|c|c|c|c|}
\hline \multirow[b]{2}{*}{ Variable } & \multicolumn{3}{|c|}{ Mean (Standard deviation) } & \multirow{2}{*}{$\begin{array}{l}95 \% \mathrm{Cl} \text { and } \mathrm{p} \\
\text { value of } \mathrm{FVG} \\
\text { vs CG }\end{array}$} & \multirow{2}{*}{$\begin{array}{l}\text { VD of } \\
\text { FVG vs } \\
\text { CG (\%) }\end{array}$} & \multirow{2}{*}{$\begin{array}{l}95 \% \mathrm{Cl} \text { and } \mathrm{p} \\
\text { value of BG } \\
\text { vs CG }\end{array}$} & \multirow{2}{*}{$\begin{array}{l}\text { VD of BG } \\
\text { vs CG (\%) }\end{array}$} \\
\hline & $\begin{array}{l}\text { FVG } \\
(n=169)\end{array}$ & BG $(n=97)$ & CG $(n=80)$ & & & & \\
\hline Age (years) & $\begin{array}{l}18.24 \\
(0.56)\end{array}$ & $\begin{array}{l}19.34 \\
(0.68)\end{array}$ & $\begin{array}{l}19.61 \\
(1.24)\end{array}$ & $\begin{array}{l}{[-1.66,-1.08]} \\
2.53 \times 10^{-15}\end{array}$ & 15 & $\begin{array}{l}{[-0.58,0.03]} \\
8.05 \times 10^{-2}\end{array}$ & 47 \\
\hline $\begin{array}{l}\text { Body Mass } \\
(\mathrm{kg})\end{array}$ & $72.0(19.4)$ & $77.1(20.4)$ & $73.7(19.3)$ & $\begin{array}{l}{[-6.9,3.5]} \\
5.21 \times 10^{-1}\end{array}$ & 46 & $\begin{array}{l}{[-2.5,9.3]} \\
2.60 \times 10^{-1}\end{array}$ & 55 \\
\hline $\begin{array}{l}\text { Body Mass } \\
\text { Index }(\mathrm{kg} / \\
\left.\mathrm{m}^{2}\right)\end{array}$ & $24.6(6.2)$ & $25.4(6.1)$ & $24.4(6.0)$ & $\begin{array}{l}{[-1.51,1.73]} \\
8.89 \times 10^{-1}\end{array}$ & 50 & $\begin{array}{l}{[-0.8,2.8]} \\
2.86 \times 10^{-1}\end{array}$ & 55 \\
\hline $\begin{array}{l}\text { Curl Up } \\
\text { (Number of } \\
\text { repetitions) }\end{array}$ & $32(9)$ & $38(9)$ & $35(10)$ & $\begin{array}{l}{[-6,-1]} \\
8.31 \times 10^{-3}\end{array}$ & $40 *$ & $\begin{array}{l}{[0,5]} \\
8.82 \times 10^{-2}\end{array}$ & $58^{*}$ \\
\hline $\begin{array}{l}\text { Sit and } \\
\text { Reach }(\mathrm{cm})\end{array}$ & $25(8)$ & $22(7)$ & $28(7)$ & $\begin{array}{l}{[-5,-1]} \\
1.20 \times 10^{-3}\end{array}$ & $38^{*}$ & $\begin{array}{l}{[-9,-5]} \\
3.63 \times 10^{-9}\end{array}$ & $26^{*}$ \\
\hline $\begin{array}{l}\text { Standing } \\
\text { Long Jump } \\
\text { (cm) }\end{array}$ & $\begin{array}{l}152.7 \\
(29.2)\end{array}$ & $\begin{array}{l}157.8 \\
(31.1)\end{array}$ & $\begin{array}{l}167.2 \\
(25.7)\end{array}$ & $\begin{array}{l}{[-21.7,-7.3]} \\
1.01 \times 10^{-4}\end{array}$ & $35^{*}$ & $\begin{array}{l}{[-17.8,-1.0]} \\
2.93 \times 10^{-2}\end{array}$ & $38 *$ \\
\hline $\begin{array}{l}\text { Cooper } \\
\text { Test }(\mathrm{m})\end{array}$ & $\begin{array}{l}26.70 \\
(7.86)\end{array}$ & $\begin{array}{l}23.64 \\
(6.51)\end{array}$ & $\begin{array}{l}30.83 \\
(9.49)\end{array}$ & $\begin{array}{l}{[-293,-77]} \\
9.48 \times 10^{-4}\end{array}$ & $38^{*}$ & $\begin{array}{l}{[-432,-211]} \\
5.60 \times 10^{-8}\end{array}$ & $28^{*}$ \\
\hline
\end{tabular}

Note: $\mathrm{Cl}=$ Confidence Interval, VD = Vargha-Delaney effect size; $*$ Significant difference. Occurs if $p \leq 0.05$ and VD $\leq 42$ $\%$ or $\mathrm{VD} \geq 58 \%$ 
Table 2. Baseline vs post comparisons, football \& volleyball (FVG, $n=169)$, badminton (BG, $n=97)$, control (CG, $n=80)$

\begin{tabular}{|c|c|c|c|c|c|c|}
\hline Variable & Group & $\begin{array}{l}\text { Baseline Mean } \\
\text { (SD) }\end{array}$ & Post Mean (SD) & $\begin{array}{l}\text { Mean } \\
\text { difference (SD) }\end{array}$ & $\mathrm{Cl}, \mathrm{p}$-value & VD (\%) \\
\hline \multirow{3}{*}{$\begin{array}{l}\text { Body Mass } \\
(\mathrm{kg})\end{array}$} & FVG & $72.0(19.4)$ & $73.4(19.7)$ & $1.4(0.2)$ & {$[1.0,1.8], 3.45 \times 10^{-10}$} & 53 \\
\hline & BG & $77.1(20.4)$ & $76.1(20.7)$ & $-1.0(2.2)$ & {$[-1.5,-0.6], 1.64 \times 10^{-5}$} & 48 \\
\hline & CG & $73.7(19.3)$ & $75.2(20.2)$ & $1.4(3.2)$ & {$[0.7,2.1], 1.15 \times 10^{-4}$} & 53 \\
\hline \multirow{3}{*}{$\begin{array}{l}\text { Body Mass } \\
\text { Index }(\mathrm{kg} / \\
\left.\mathrm{m}^{2}\right)\end{array}$} & FVG & $24.6(6.2)$ & $25.0(6.3)$ & $0.5(0.1)$ & {$[0.4,0.6], 1.38 \times 10^{-10}$} & 53 \\
\hline & BG & $25.4(6.1)$ & $25.1(6.2)$ & $-0.3(0.7)$ & {$[-0.5,-0.2], 1.60 \times 10^{-5}$} & 48 \\
\hline & CG & $24.4(6.0)$ & $24.9(6.2)$ & $0.5(1.0)$ & {$[0.2,0.7], 1.12 \times 10^{-4}$} & 53 \\
\hline \multirow{3}{*}{$\begin{array}{l}\text { Curl Up } \\
\text { (Number of } \\
\text { repetitions) }\end{array}$} & FVG & $32(9)$ & $40(9)$ & $8(0)$ & {$[7,9], 1.75 \times 10^{-42}$} & $75^{*}$ \\
\hline & BG & $38(9)$ & $42(9)$ & $4(6)$ & {$[3,5], 2.06 \times 10^{-9}$} & $64 *$ \\
\hline & CG & $35(10)$ & $30(9)$ & $-5(5)$ & {$[-6,-4], 2.03 \times 10^{-13}$} & $35^{*}$ \\
\hline \multirow{3}{*}{$\begin{array}{l}\text { Sit and } \\
\text { Reach }(\mathrm{cm})\end{array}$} & FVG & $25(8)$ & $29(7)$ & $4(0)$ & {$[3,5], 2.20 \times 10^{-23}$} & $65^{*}$ \\
\hline & $\mathrm{BG}$ & $22(7)$ & $25(7)$ & $3(3)$ & {$[3,4], 2.95 \times 10^{-16}$} & $64 *$ \\
\hline & CG & $28(7)$ & $26(7)$ & $-3(4)$ & {$[-4,-2], 3.96 \times 10^{-9}$} & $40^{*}$ \\
\hline \multirow{3}{*}{$\begin{array}{l}\text { Standing } \\
\text { Long Jump } \\
(\mathrm{cm})\end{array}$} & FVG & $152.7(29.2)$ & $163.9(26.9)$ & $11.2(1.4)$ & {$[8.3,14.0], 7.12 \times 10^{-13}$} & $62 *$ \\
\hline & BG & $157.8(31.1)$ & $166.6(31.5)$ & $8.8(14.2)$ & {$[5.9,11.6], 2.68 \times 10^{-8}$} & $60 *$ \\
\hline & CG & $167.2(25.7)$ & $156.4(30.6)$ & $-10.8(17.2)$ & {$[-14.6,-7.0], 2.95 \times 10^{-7}$} & $39 *$ \\
\hline \multirow{3}{*}{$\begin{array}{l}\text { Cooper Test } \\
\text { (m) }\end{array}$} & FVG & 1699 (352) & $1840(370)$ & $141(23)$ & {$[95,187], 8.30 \times 10^{-9}$} & $62 *$ \\
\hline & $\mathrm{BG}$ & $1563(291)$ & $1737(315)$ & $175(211)$ & {$[132,217], 1.44 \times 10^{-12}$} & $66 *$ \\
\hline & CG & $1884(424)$ & $1672(434)$ & $-212(242)$ & {$[-266,-159], 1.78 \times 10^{-11}$} & $36 *$ \\
\hline
\end{tabular}

Note: $\mathrm{Cl}=$ Confidence Interval, $\mathrm{VD}=$ Vargha-Delaney effect size; *Significant difference. Occurs if $\mathrm{p} \leq 0.05$ and VD $\leq 42$ $\%$ or VD $\geq 58 \%$

Table 3. Differences between exercise groups and control group

\begin{tabular}{|c|c|c|c|c|c|c|c|c|}
\hline \multicolumn{9}{|l|}{ Welch T-Test } \\
\hline \multirow[b]{2}{*}{ Variable } & \multicolumn{4}{|c|}{ Mean (Standard deviation) } & \multirow{2}{*}{$\begin{array}{l}95 \% \mathrm{Cl} \text { and } \\
\mathrm{p} \text { value of } \\
\text { FVG vs CG }\end{array}$} & \multirow[b]{2}{*}{$\begin{array}{l}\text { VD of FVG } \\
\text { vs CG (\%) }\end{array}$} & \multirow{2}{*}{$\begin{array}{l}95 \% \mathrm{Cl} \text { and } \\
p \text { value of } \\
\text { BG vs CG }\end{array}$} & \multirow[b]{2}{*}{$\begin{array}{l}\text { VD of BG vs } \\
\text { CG (\%) }\end{array}$} \\
\hline & $\begin{array}{l}\text { FVG } \\
(n=169)\end{array}$ & \multicolumn{2}{|c|}{ BG $(n=97)$} & CG $(n=80)$ & & & & \\
\hline Body Mass & $73.4(19.7)$ & \multicolumn{2}{|c|}{$76.1(20.7)$} & $75.2(20.2)$ & \multirow{2}{*}{$\begin{array}{l}{[-7.1,3.7]} \\
5.30 \times 10^{-1} \\
{[-1.5,1.8]} \\
8.72 \times 10^{-1}\end{array}$} & 46 & \multirow{2}{*}{$\begin{array}{l}{[-5.2,7.0],} \\
7.66 \times 10^{-1} \\
{[-1.7,2.0]} \\
2.54 \times 10^{-25}\end{array}$} & 51 \\
\hline $\begin{array}{l}\text { Body Mass } \\
\text { Index }\left(\mathrm{kg} / \mathrm{m}^{2}\right)\end{array}$ & $25.0(6.3)$ & \multicolumn{2}{|c|}{$25.1(6.2)$} & $24.9(6.2)$ & & 51 & & 51 \\
\hline $\begin{array}{l}\text { Standing } \\
\text { Long Jump } \\
\text { (cm) }\end{array}$ & \multicolumn{3}{|l|}{$11.2(1.4)^{\mathrm{a}}$} & $\begin{array}{l}-10.8 \\
(17.2)^{a}\end{array}$ & $\begin{array}{l}{[17.2,26.7]} \\
1.97 \times 10^{-16}\end{array}$ & $82 * a$ & --- & --- \\
\hline \multicolumn{9}{|l|}{ ANCOVA } \\
\hline \multirow[b]{2}{*}{ Variable } & \multicolumn{4}{|c|}{ Adjusted Mean (Standard Error) } & \multirow{2}{*}{$\begin{array}{l}95 \% \mathrm{Cl} \text { and } \\
\mathrm{p} \text { value of } \\
\text { FVG vs CG }\end{array}$} & \multirow{2}{*}{$\begin{array}{l}\text { Omega- } \\
\text { squared/ } \\
\text { CLES FVG } \\
\text { vs CG (\%) }\end{array}$} & \multirow{2}{*}{$\begin{array}{l}95 \% \mathrm{Cl} \text { and } \\
\mathrm{p} \text { value of } \\
\text { BG vs CG }\end{array}$} & \multirow{2}{*}{$\begin{array}{l}\text { Omega- } \\
\text { squared/ } \\
\text { CLES BG vs } \\
\text { CG (\%) }\end{array}$} \\
\hline & FVG & CG & BG & CG & & & & \\
\hline \multirow{4}{*}{$\begin{array}{l}\text { Curl Up } \\
\text { (Number of } \\
\text { repetitions) } \\
\text { Sit and Reach } \\
\text { (cm) } \\
\text { Standing } \\
\text { Long Jump } \\
\text { (cm) } \\
\text { Cooper Test } \\
\text { (m) }\end{array}$} & $41(0)$ & $28(1)$ & $41(1)$ & $31(1)$ & $\begin{array}{l}{[11,14]} \\
4.32 \times 10^{-45}\end{array}$ & $33 * / 69$ & \multirow{2}{*}{$\begin{array}{l}{[8,12],} \\
2.54 \times 10^{-25} \\
{[4,6],} \\
9.59 \times 10^{-17} \\
{[14.2,}\end{array}$} & $22 * / 66$ \\
\hline & $30(0)$ & $24(0)$ & $28(0)$ & $22(0)$ & $\begin{array}{l}{[5,7],} \\
3.76 \times 10^{-23}\end{array}$ & $14 * / 62$ & & $11^{*} / 61$ \\
\hline & --- & --- & $\begin{array}{l}170.5 \\
(1.6)\end{array}$ & $\begin{array}{l}151.6 \\
(1.8)\end{array}$ & --- & --- & $\begin{array}{l}{[14.2,} \\
23.7] \\
237 \times 10^{-13}\end{array}$ & $9 * / 60$ \\
\hline & $\begin{array}{l}1885 \\
(21)\end{array}$ & $\begin{array}{l}1577 \\
(31)\end{array}$ & $\begin{array}{l}1860 \\
(23)\end{array}$ & $\begin{array}{l}1523 \\
(26)\end{array}$ & $\begin{array}{l}{[234,382]} \\
1.19 \times 10^{-14}\end{array}$ & $12 * / 61$ & $\begin{array}{l}{[266,409],} \\
6.85 \times 10^{-17}\end{array}$ & $17^{*} / 64$ \\
\hline
\end{tabular}

Note: $\mathrm{Cl}=$ Confidence Interval, $\mathrm{VD}=$ Vargha-Delaney effect size, CLES = Common Language Effect Size; *Significant difference. Occurs if $p \leq 0.05$ and $V D \leq 42 \%$ or VD $\geq 58 \%$, or if $p \leq 0.05$ and CLES $\geq 58 \%$; $a=$ Mean differences compared 
within the CG. Table 3 shows the results of comparing the fitness parameters of the PE groups with the CG after 12 weeks. The overall fitness of students in the PE groups was significantly better than the fitness of CG.

\section{Discussion}

The aim of this study was to examine if a pre-requisite PE course for graduation will improve the health-related fitness parameters of the students. The exercises provided to the students were done in eight weeks. The results show that there is a significant improvement in the healthrelated fitness of students who took the PE course. This agrees with studies done on school children [17, 29-32] and university students [33-37]. Moreover, the current study shows evidence that the benefits of recreational football [38, 39] can be obtained to a certain degree in a classroom setting. The current study also adds to previous studies that show that volleyball is beneficial for healthrelated fitness [34, 40, 41]. As for the effects of badminton on health-related fitness, this is the first study to our knowledge that reveals the effects of badminton training on non-athletes. Given the aerobic and anaerobic energy demand needed to play football [42], volleyball [43, 44], badminton [45], it is likely that the training drills and competitions were the reason for the improvements in the fitness of the students who took the courses.

Nevertheless, there was a difference between this study and the study by Liu et al. [33]. They pointed out that flexibility did not significantly improve after their PE program. Meanwhile, flexibility improved in both groups in this study. The difference may be because both studies had different programs. Liu et al. [33] only gave basic training for one activity each week for 11 weeks. Moreover, Liu et al. pointed out that the exercise programs did not have enough time to improve the flexibility of the students [33]. On the other hand, the students in this study did a maximum of two games during the eight weeks, were given basic training in these games, and competed with each other. The competitions might have helped increased total energy expenditure in addition to the fitness training and fundamental skills training sessions. This is because training sessions generally require less energy expenditure than match sessions [46].

Another difference from this study and that from Liu et al. [33] is that the students in the FVG did not experience a change in body composition. However, this could be attributed to the fact that the measures of body composition used in this study are not adequate to show any change in this parameter.

Interestingly, the health-related fitness parameters of students in the CG reduced after eight weeks, especially considering that they had a greater fitness level than the exercise groups before the program. This indicates that students who do not participate in a PE course may lose their fitness if they do not do any sort of activity apart from studying.

\section{Importance}

The results show that providing the basic skills of the games will not prevent the improvements in healthrelated fitness as long as competitions are included in the PE program. This point is important for students who are playing these games for their first time. Thus, students whose course load is a barrier to engaging in physical activity can obtain some benefits of regular physical activity by registering for a PE course, even if it is their first time to practice the sport. These results may give more supporting reason to students who believe they may benefit from a university PE course.

It was shown that the physical activity behaviors of students who were not highly active can change when PE courses are implemented at the university level [47, 48]. Moreover, there is evidence that university students who took a PE course required for graduation have a higher chance of being positively influenced to continue the sports activities they learned at the university after graduation $[49,50]$. Thus, presenting to university students the benefits of the PE courses on their healthrelated fitness will be needed to encourage them to further engage in physical activity outside of class time and after graduation.

\section{Limitations and recommendations}

A limitation of the study was that the exercise and dietary habits of the students before and during the study period was unknown. It was assumed that the students had similar exercise and dietary habits before and during the study. Moreover, this study was conducted only with male students. It is suggested that a similar study with a control group is conducted with female university students or a mixed-sex group. Thirdly, there is no guarantee that the students gave their maximum effort during the testing periods even after been encouraged to do so.

\section{Conclusions}

There is evidence that sports such as football, volleyball, and badminton can help improve healthrelated fitness levels of male university students in PE university program. Thus, they can contribute to the weekly physical activity doses required to keep healthy. Moreover, students who do not participate in a PE course may be at risk of losing their fitness.

\section{Financial support statement*}

The authors did not receive any financial support.

\section{Acknowledgements*}

The author acknowledges King Fahd University of Petroleum \& Minerals for making this study possible. The author also thanks the instructors, statistical personnel, and the students who participated in the study.

\section{Conflict of interest}

There were no conflicts of interest. 


\section{References}

1. Couturier L, Chepko S, Hill R, Holt S, Persse D, Rettig B, et al. Grade-Level Outcomes for K-12 Physical Education. SHAPE America; 2013.

2. Cardinal BJ, Jacques KM, Levy SS. Evaluation of a university course aimed at promoting exercise behavior. $J$ Sports Med Phys Fitness. 200242(1):113-9.

3. Cardinal BJ, Sorensen SD, Cardinal MK. Historical Perspective and Current Status of the Physical Education Graduation Requirement at American 4-Year Colleges and Universities. Res Q Exerc Sport. 2012;83(4):503- 12. https://doi.org/10.1080/02701367.2012.10599139

4. Cardinal BJ. Physical Activity Education's Contributions to Public Health and Interdisciplinary Studies: Documenting More than Individual Health Benefits. $J$ Phys Educ Recreat Dance. 2016;87(4):3- 5. https://doi.org/10.1080/07303084.2016.1142182

5. Lackman J, Smith ML, McNeill EB. Freshman College Students' Reasons for Enrolling in and Anticipated Benefits from a Basic College Physical Education Activity Course. Front Public Health, 2015;3. https://doi.org/10.3389/fpubh.2015.00162

6. Andersen LB, Froberg K, Kristensen PL, Moller NC, Resaland GK, Anderssen SA. Secular trends in physical fitness in Danish adolescents. Scand J Med Sci Sports. 2010;20(5):757-63. https://doi.org/10.1111/j.1600-0838.2009.00936.x

7. Dos Santos FK, Prista A, Gomes TNQF, Daca T, Madeira A, Katzmarzyk PT, et al. Secular trends in physical fitness of Mozambican school-aged children and adolescents. Am J Hum Biol. 2015;27(2):201-6. https://doi.org/10.1002/ajhb.22638

8. Dyrstad SM, Berg T, Tjelta LI. Secular trends in aerobic fitness performance in a cohort of Norwegian adolescents. Scand J Med Sci Sports. 2012;22(6):822-7. https://doi.org/10.1111/j.1600-0838.2011.01315.x

9. Huotari PRT, Nupponen H, Laakso L, Kujala UM. Secular trends in muscular fitness among Finnish adolescents. Scand J Public Health. 2010;38(7):739-47. https://doi.org/10.1177/1403494810384425

10.Moliner-Urdiales D, Ruiz JR, Ortega FB, JiménezPavón D, Vicente-Rodriguez G, Rey-López JP, et al. Secular trends in health-related physical fitness in Spanish adolescents: The AVENA and HELENA Studies. J Sci Med Sport. 2010;13(6):584-8. https://doi.org/10.1016/j.jsams.2010.03.004

11.Okely AD, Hardy LL, Booth ML, Dobbins TA, DenneyWilson EA, Yang B. Changes in cardiorespiratory fitness among children and adolescents in Australia: 1997 and 2004. J Sports Sci. 2010;28(8):851-7. https://doi.org/10.1080/02640411003716959

12.Kaj M, Tékus É, Juhász I, Stomp K, Wilhelm M. Changes in physical fitness of Hungarian college students in the last fifteen years. Acta Biol Hung. 2015;66(3):270-81. https://doi.org/10.1556/018.66.2015.3.3

13. Shields M, Tremblay MS, Laviolette M, Craig CL, Janssen I, Gorber SC. Fitness of Canadian adults: Results from the 2007-2009 Canadian health measures survey. Health Rep. 2010;21(1):21.

14. Wetter AC, Wetter TJ, Schoonaert KJ. Fitness and Health in College Students: Changes across 15 Years of Assessment. $J$ Exerc Physiol Online. 2013;16(5).

15.World Health Organization. WHO. Obesity and overweight [Internet]. World Health Organization. 2016 [cited 2017 Mar 14]. Available from: http://www.who.int/mediacentre/ factsheets/fs311/en/

16.Minatto G, Petroski EL, Silva DAS. Health-related physical fitness in Brazilian adolescents from a small town of German colonization. Rev Andal Med Deporte. 2016;9(2):67-74. https://doi.org/10.1016/j.ramd.2014.09.003

17.Sun C, Pezic A, Tikellis G, Ponsonby A-L, Wake M, Carlin $\mathrm{JB}$, et al. Effects of school-based interventions for direct delivery of physical activity on fitness and cardiometabolic markers in children and adolescents: a systematic review of randomized controlled trials. Obes Rev. 2013;14(10):818-38. https://doi.org/10.1111/obr.12047

18.American College of Sports Medicine. ACSM's HealthRelated Physical Fitness Assessment Manual. Fourth edition. Philadelphia: Lippincott Williams \& Wilkins; 2013.

19. Gain Scores, Analysis of. Encyclopedia of Research Design, 2455 Teller Road, Thousand Oaks California 91320 United States: SAGE Publications, Inc.; 2010. https://doi.org/10.4135/9781412961288.n162

20.AllisonDB,AntoineLH,GeorgeBJ.Incorrectstatisticalmethod in parallel-groups RCT led to unsubstantiated conclusions. Lipids Health Dis, 2016;15:77, s12944-016-0242-3. https://doi.org/10.1186/s12944-016-0242-3.

21.R Core Team. $R$ : A language and environment for statistical computing [Internet]. 2017. Vienna, Austria: R Foundation for Statistical Computing. [updated 2019 Jan 1; cited 2019 Apr 8]. Available from: https://www.R-project.org/

22.Lakens D. Calculating and reporting effect sizes to facilitate cumulative science: a practical primer for t-tests and ANOVAs. Front Psychol, 2013;4. https://doi.org/10.3389/fpsyg.2013.00863

23.Vargha A, Delaney HD. A Critique and Improvement of the CL Common Language Effect Size Statistics of McGraw and Wong. J Educ Behav Stat. 2000;25(2):101-32.

24.Rogmann JJ. Ordinal Dominance Statistics (orddom): An $R$ Project for Statistical Computing package to compute ordinal, nonparametric alternatives to mean comparison (Version 3.1). [Internet]. 2013. [cited 2020 Apr 7]. Available from: http://cran.r-project.org/

25.Torchiano M. effsize: Efficient Effect Size Computation [Internet]. 2019. [cited 2020 Apr 7]. Available from: https:// CRAN.R-project.org/package $=$ effsize

26.Lüdecke D. sjstats: Statistical Functions for Regression Models (Version 0.18.0) [Internet]. 2020 [cited 2020 May 7]. Available from: https://CRAN.R-project.org/package=sjstats

27.Lenhard W, Lenhard A. Calculation of Effect Sizes [Internet]. Unpublished; 2017 [cited 2020 Apr 7]. Available from: https://www.psychometrica.de/effect_size.html

28.Peng C-YJ, Chen L-T. Beyond Cohen's d: Alternative Effect Size Measures for BetweenSubject Designs. $J$ Exp Educ. 2014;82(1):22-50. https://doi.org/10.1080/00220973.2012.745471

29.Czarniecka R, Milde K, Tomaszewski P. Changes in strength abilities of adolescent girls: the effect of a 3 -year physical education curriculum. Biomedical Human Kinetics, 2012;4. https://doi.org/10.2478/v10101-012-0019-8

30.Jarani J, Grøntved A, Muca F, Spahi A, Qefalia D, Ushtelenca K, et al. Effects of two physical education programmes on health- and skill-related physical fitness of Albanian children. J Sports Sci. 2016;34(1):35-46. https://doi.org/10.1080/02640414.2015.1031161

31. Minatto G, Barbosa Filho VC, Berria J, Petroski EL. School-Based Interventions to Improve Cardiorespiratory Fitness in Adolescents: Systematic Review with Meta-analysis. Sports Med. 2016;46(9):1273-92. 
https://doi.org/10.1007/s40279-016-0480-6

32.Sdrolias P. The effect of the Manitoba grade 11 and 12 high school physical education curriculum on fitness-related health, academic and behavioural outcomes [Internet] [M.Sc.]. [Canada]: University of Manitoba (Canada); 2009. [cited 2020 Apr 7]. Available from: https://searchproquest-com.sdl.idm.oclc.org/docview/637049488/ abstract/1A3EE01640C640BFPQ/1

33.Liu J, Shangguan R, Keating XD, Leitner J, Wu Y, Liu J, et al. A conceptual physical education course and college freshmen's health-related fitness. Health Educ. 2017;117(1):53-68. https://doi.org/10.1108/HE-01-2016-0002

34.Mohammed MHH. Effect of a Volleyball Course on Health-Related Fitness Components of University Students. Sport Mont. 2018;16(1):41-3. https://doi.org/10.26773/smj.180209

35.Warren B (BJ), Odenheimer Brin E. Advancing the physical activity curriculum at the collegiate level. Health Educ. 2017;117(4):372-81. https://doi.org/10.1108/HE-07-2016-0026

36.Ibrahim S, Alameer AH, Azeem K, Al Moslim H. The effect of physical education program on the physical fitness levels of the orientation students of King Fahd University of Petroleum and Minerals. J Phys Educ Sport Pitesti. 2013;13(2):203-8.

37.Azeem K, Mohammed MHH. The Effect of Resistance Training on the Selected Physical and Physiological Variables of the Male Students. International Journal of Pharmaceutical Research \& Allied Sciences, 2019;8(2): 198-205.

38.Milanović Z, Pantelić S, Čović N, Sporiš G, Krustrup P. Is Recreational Soccer Effective for Improving $\dot{V}$ O2max? A Systematic Review and Meta-Analysis. Sports Med. 2015;45(9):1339-53. https://doi.org/10.1007/s40279-015-0361-4

39.Milanović Z, Pantelić S, Čović N, Sporiš G, Mohr M, Krustrup P. Broad-spectrum physical fitness benefits of recreational football: a systematic review and metaanalysis. $B r \quad J$ Sports Med. 2019;53(15):926-39. https://doi.org/10.1136/bjsports-2017-097885

40.Leung K-M, Chung P-K, Hagger MS. The effects of light volleyball intervention programme in improving selected physical and psychological attributes of older adults in Hong Kong. Int J Sport Exerc Psychol. 2020;18(1):1-12. https://doi.org/10.1080/1612197X.2018.1462231
41.Sozen H. The Effect of Volleyball Training on the Physical Fitness of High School Students. Procedia - Soc Behav Sci. 2012;46:1455-60. https://doi.org/10.1016/j.sbspro.2012.05.320

42.Stølen T, Chamari K, Castagna C, Wisløff U. Physiology of Soccer. Sports Med. 2005;35(6):501-36. https://doi.org/10.2165/00007256-200535060-00004

43.Lidor R, Ziv G. Physical and Physiological Attributes of Female Volleyball Players-A Review. $J \quad$ Strength Cond Res. 2010;24(7):1963-73. https://doi.org/10.1519/JSC.0b013e3181ddf835

44.Tsoukos A, Drikos S, Brown LE, Sotiropoulos $\mathrm{K}$, Veligekas P, Bogdanis GC. Anthropometric and Motor Performance Variables are Decisive Factors for the Selection of Junior National Female Volleyball Players. J Hum Kinet. 2019;67(1):163-73. https://doi.org/10.2478/hukin-2019-0012

45.Phomsoupha M, Laffaye G. The Science of Badminton: Game Characteristics, Anthropometry, Physiology, Visual Fitness and Biomechanics. Sports Med. 2015;45(4):473-95. https://doi.org/10.1007/s40279-014-0287-2

46.Fédération Internationale de Football Association. Nutrition for Football: A practical guide to eating and drinking for health and performance [Internet]. Fédération Internationale de Football Association Member Associations and Development; 2005 [cited 2020 Apr 22]. Available from: https://www.fifa.com/mm/document/footballdevelopment/ medical/51/55/15/nutritionbooklet_neue2010.pdf

47.DeVoe D, Kennedy C, Ransdell L, Pirson B, DeYoung W, Casey K. Impact of Health, Fitness, and Physical Activity Courses on the Attitudes and Behaviors of College Students. $J$ Gend Cult Health. 1998;3(4):243-55.

48.Sallis JF, Calfas KJ, Nichols JF, Sarkin JA, Johnson MF, Caparosa S, et al. Evaluation of a University Course to Promote Physical Activity: Project GRAD. Res $Q$ Exerc Sport. 1999;70(1):1-10. https://doi.org/10.1080/02701367.1999.10607725

49. Silas N. Pearman III MAD, Robert F. Valois PhD M, PhD RGS, PhD RPS, J. Wanzer Drane PE P, PhD CAM. The Impact of a Required College Health and PhysicalEducation Course on the Health Status of Alumni. J Am Coll Health. 1997;46(2):77-85. https://doi.org/10.1080/07448489709595591

50.Sparling PB. College physical education: an unrecognized agent of change in combating inactivity-related diseases. Perspect Biol Med. 2003;46(4):579-87. https://doi.org/10.1353/pbm.2003.0091 


\section{Information about the author:}

Mohammed H.H. Mohammed; https://orcid.org/0000-0002-7193-2185; hamdan@kfupm.edu.sa; Department of Physical Education, King Fahd University of Petroleum \& Minerals; Dhahran, Saudi Arabia.

\section{Cite this article as:}

Mohammed H.H. Mohammed. The effect of three sport games in physical education on the health-related fitness of male university students. Physical education of students, 2020;24(4):251-258.

https://doi.org/10.15561/20755279.2020.0408

This is an Open Access article distributed under the terms of the Creative Commons Attribution License, which permits unrestricted use, distribution, and reproduction in any medium, provided the original work is properly cited http://creativecommons.org/licenses/by/4.0/deed.en

Received: 18.04.2020

Accepted: 28.05.2020; Published: 30.08.2020 